\title{
EFFECT OF REGIONAL OWN REVENUE, GENERAL ALLOCATION OF FUND AND SPECIAL ALLOCATION OF FUND FOR CAPITAL EXPENDITURE BUDGET ALLOCATION.
}

(Case Study Realization Reports on The Central Java Province Regional Expenditure and Revenue Budget the year 2010-2013)

Saifudin dan Septiana Sari

saifudin@usm.ac.id, septiana1149@gmail.com

Universitas Semarang (USM)

\begin{abstract}
The purpose of first regional autonomy for increase service public and economy every regional. The purpose of research for is to determine whether there is the of the Region Own Revenue, General Allocation Fund and Special Allocation of Fund for Capital Expenditure Budget Allocation.

The Population of research this is all government District and City in Central Java of twenty nine District and Six City. The research used secondary data of Actual Income and Expenditure budget realization report of Government province Central Java the years of 2010-2013. The way to analyze the data by using multiple linier regression analysis.

Based on the result of this research concluded that partially Regional Own Revenue and General Allocation Fund has of the effect on Budget Capital Expenditure. While the Special Allocation Fund does not effect on Budget Capital Expenditure. Simultaneously, The Regional Own Revenue, General Allocation Fund and Special Allocation Fund effect on Budget Capital Expenditure.

Keywords : Regional Own Revenue, General Allocation Fund, Special Allocation Fund, Capital Expenditure, and Regional Autonomy.
\end{abstract}

\section{PENDAHULUAN}

Masa sentralisasi pemerintahan telah berakhir diganti dengan otonomi daerah. Berdasarkan UU No. 32 tahun 2004, setiap daerah diberi kewenangan yang luas untuk mengurus rumah tangganya sendiri dengan sedikit mungkin adanya campur tangan dari pemerintah pusat. UU No. 32 tahun 2004 menjelaskan pula bahwa pemberian otonomi luas kepada pemerintah daerah diarahkan untuk mempercepat terwujudnya kesejahteraan masyarakat melalui peningkatan pelayanan, pemberdayaan dan peran serta masyarakat. Dengan kata lain, tujuan dari otonomi daerah adalah untuk menciptakan kemandirian daerah dalam meningkatkan kesejahteraan dan pelayanan publik, pengembangan kehidupan berdemokrasi, keadilan, pemerataan, dan pemeliharaan hubungan yang serasi antara pusat dan daerah serta antar daerah (Arwati dan Hadiati, 2013).

Anggaran daerah merupakan rencana keuangan yang dijadikan pedoman Pemerintah Daerah dalam memberikan pelayanan kepada publik. Di Indonesia, anggaran daerah biasa disebut dengan Anggaran Pendapatan dan Belanja Daerah (APBD). Seluruh penerimaan dan pengeluaran Pemerintah Daerah baik dalam bentuk uang, barang dan jasa pada tahun anggaran yang harus dianggarakan dalam APBD (Kawedar, 2008). Pengelolaan keuangan daerah yang baik akan berpengaruh terhadap kemajuan suatu daerah. Pengelolaan keuangan daerah yang dilakukan secara ekonomis, efisien dan efektif atau memenuhi kriteria value for money serta transparansi, akuntanbilitas dan keadilan akan dapat mendorong pertumbuhan ekonomi. Pengelolaan keuangan daerah yang baik 
tidak hanya sumber daya manusia yang handal, namun didukung dengan kemampuan keuangan daerah yang memadai.

Laporan keuangan merupakan laporan yang terstruktur mengenai posisi keuangan dan transaksi-transaksi yang dilakukan oleh suatu entitas pelaporan. Tujuan umum laporan keuangan adalah menyajikan informasi mengenai posisi keuangan, realisasi anggaran, arus kas dan kinerja keuangan suatu entitas pelaporan yang bermanfaat bagi para pengguna dalam membuat dan mengevaluasi keputusan mengenai alokasi sumber daya (Kawedar, 2008).

Setiap daerah memiliki tingkat kemandirian daerah dan kemampuan keuangan yang tidak sama dalam mendanai kegiatan-kegiatannya. Hal ini dapat menimbulkan ketimpangan fiskal antara satu daerah dengan daerah lainya. Untuk mengatasi ketimpangan fiskal, pemerintah mengalokasikan dana yang bersumber dari APBN untuk mendanai kebutuhan daerah dalam pelaksanaan desentralisasi (Mentayani, 2013). Penciptaan terhadap kemandirian daerah merupakan kewenangan pemerintah daerah yang harus berupaya meningkatkan mutu pelayanan publik dan perbaikan dalam berbagai sektor yang berpotensi untuk dikembangkan menjadi sumber pendapatan asli daerah. Karena setiap daerah mempunyai kemampuan keuangan yang tidak sama dalam mendanai kegiatan-kegiatannya, hal inilah yang menimbulkan ketimpangan fiskal antara satu daerah dengan daerah yang lain. Oleh karena itu, untuk mengatasi hal ini pemerintah mengalokasikan dana yang bersumber dari APBD untuk mendanai kebutuhan daerah dalam pelaksanaan desentralisasi.

Perubahan alokasi belanja ditujukan untuk pembangunan berbagai fasilitas modal. Pemerintah perlu memfasilitasi berbagai aktivitas peningkatan perekonomian, salah satunya dengan membuka kesempatan berinvestasi. Pembangunan infrastruktur dan pemberian berbagai fasilitas kemudahan dilakukan untuk meningkatkan daya tarik investasi. Pembangunan infrastruktur industri mempunyai dampak yang nyata terhadap kenaikan pendapatan asli daerah (PAD). Dengan kata lain, pembangunan berbagai fasilitas ini akan berujung pada peningkatan kemandirian daerah (Adi, 2006).

Permasalahan yang dihadapi pemerintah daerah dalam organisai sektor publik mengenai pengalokasian anggaran. Pengalokasian anggaran merupakan jumlah alokasi dana yang digunakan untuk masing-masing program kegiatan. Dengan sumber daya yang terbatas, pemerintah daerah harus dapat mengalokasikan penerimaan yang diperoleh untuk belanja daerah yang bersifat produktif. Pemerintah memiliki anggaran relative terbatas dalam Anggaran Pendapatan dan Belanja Negara (APBN). Pemerintah telah meningkatkan anggaran belanja modal dan pembangunan infrastruktur, tetapi Anggaran Pendapatan dan Belanja Negara (APBN) untuk pembangunan infrastruktur masih dinilai belum mencukupi. Pemerintah lebih banyak mengalokasikan belanjanya pada sectorsektor yang kurang diperlukan dibandingkan untuk meningkatkan pelayanan publik (Nuarisa, 2013).

Belanja modal pada umumnya dialokasikan untuk perolehan aset tetap yang dapat digunakan sebagai sarana pembangunan daerah. Dengan berkembang pesatnya pembangunan diharapkan terjadi peningkatan kemandirian daerah dalam membiayai kegiatannya terutama dalam hal keuangan. Untuk dapat mengetahui terjadinya peningkatan kemandirian daerah, pendapatan asli daerah bisa dijadikan sebagai tolak ukurnya karena pendapatan asli daerah sendiri merupakan komponen yang penting yang mencerminkan bagaimana sebuah daerah dapat mendanai sendiri kegiatannya melalui komponen pendapatan yang murni dihasilkan melalui daerah tersebut. Berangkat dari fenomena diatas peneliti tertarik untuk melakukan penelitian lebih mendalam. 


\section{TINJAUAN PUSTAKA}

Pendapatan Asli Daerah

Berdasarkan Undang-Undang Nomor 33 Tahun 2004 tentang Perimbangan Keuangan Antara Pemerintah Pusat dan Pemerintahan Daerah, Pendapatan Asli Daerah adalah pendapatan yang diperoleh Daerah yang dipungut berdasarkan Peraturan Daerah sesuai dengan peraturan perundang-undangan. Pendapatan Asli Daerah bertujuan memberikan kewenangan kepada Pemerintah Daerah untuk mendanai pelaksanaan otonomi daerah sesuai dengan potensi Daerah sebagai perwujudan Desentralisasi.

Pendapatan Daerah adalah hak dan kewajiban dalam rangka penyelenggaraan pemerintah daerah yang dapat dinilai dengan uang termasuk didalamnya segala bentuk kekayaan yang berhubungan dengan hak dan kewajiban daerah tersebut (PP RI No. 58 Tahun 2005).

\section{Dana Alokasi Umum}

Dana Alokasi Umum diberikan pemerintah pusat untuk membiayai kekurangan dari pemerintah daerah dalam memanfaatkan PAD-nya. Dana Alokasi Umum "Block Grant" yang berarti penggunaannya diserahkan kepada daerah sesuai dengan prioritas dan kebutuhan daerah untuk peningkatan pelayanan kepada masyarakat dalam rangka pelaksanaan otonomi daerah. Dana Alokasi Umum terdiri dari Dana Alokasi Umum untuk Daerah propinsi dan Dana Alokasi Umum untuk daerah Kabupaten/Kota. Jadi Dana Alokasi Umum dialokasikan untuk daerah propinsi dan untuk daerah kabupaten/kota ditetapkan sesuai dengan imbangan kewenangan antara propinsi dan Kabupaten/Kota. Ketimpangan ekonomi antara satu provinsi dengan provinsi lain tidak dapat dihindari dengan adanya desentralisasi fiskal. Disebabkan oleh minimnya sumber pajak dan Sumber Daya Alam yang kurang dapat digali oleh Pemerintah Daerah. Untuk menanggulangi ketimpangan tersebut, pemerintah pusat berinisiatif untuk memberikan subsidi berupa DAU kepada daerah.bagi daerah yang tingkat kemiskinannya lebih tinggi, akan diberikan DAU lebih besar dibanding daerah yang kaya dan begitu juga sebaliknya. Selain itu untuk mengurangi ketimpangan dalam kebutuhan pembiayaan dan penugasan pajak antara pusat dan daerah telah diatasi dengan adanya kebijakan bagi hasil dan Dana Alokasi Umum minimal sebesar 26\% dari penerimaan Dalam Negeri. Dana Alokasi Umum akan memberikan kepastian bagi daerah dalam memperoleh sumber pembiayaan untuk membiayai kebutuhan pengeluaran yang menjadi tanggung jawab masing-masing daerah (Wenas dkk, 2014).

\section{Dana Alokasi Khusus}

Dana alokasi khusus (DAK) dialokasikan dari APBN kepada daerah tertentu dalam rangka pendanaan pelaksanaan desentralisasi untuk mendanai kegiatan khusus yang ditentukan pemerintah atas dasar prioritas nasional, dan juga untuk mendanai kegiatan khusus yang diusulkan daerah tertentu. Penyusunan kegiatan khusus yang ditentukan oleh pemerintah tersebut dikoordinasi dengan gubernur, sedangkan penyusunan kegiatan khusus dilakukan setelah dikoordinasikan oleh daerah yang bersangkutan. Berdasarkan Undang-undang No. 33 tahun 2004 Besaran Dana Alokasi Khusus ditetapkan setiap tahun dalam Anggaran Pendapatan dan Belanja Negara, Dana Alokasi Khusus dialokasikan kepada Daerah tertentu untuk mendanai kegiatan khusus yang merupakan urusan Daerah. Daerah penerima Dana Alokasi Khusus wajib menyediakan Dana Pendamping sekurang-kurangnya 10\% (sepuluh persen) dari alokasi Dana Alokasi Khusus. 


\section{Belanja Modal}

Menurut Standar Akuntansi Pemerintah (SAP), belanja modal adalah pengeluaran yang dilakukan dalam rangka pembentukan modal yang sifatnya menambah aset tetap/inventaris yang memberikan manfaat lebih dari satu periode akuntansi, termasuk di dalamnya adalah pengeluaran untuk biaya pemeliharaan yang sifatnya mempertahankan atau menambah masa manfaat, serta meningkatkan kapasitas dan kualitas aset. Dalam Standar Akuntansi Pemerintah (SAP), belanja modal terdiri dari beberapa jenis belanja modal, diantaranya adalah :

1. Belanja Modal Tanah adalah pengeluuaran/biaya yang digunakan, dan untuk pengadaan / pembelian / pembebasan, penyelesaian, balik nama dan sewa tanah, pengosongan, pengurugan, perataan, pematangan tanah, pembuatan sertifikat, dan pengeluaran lainnya sehubungan dengan perolehan hak atas tanah dan sampai tanah dimaksud dalam kondisi siap pakai.

2. Belanja Modal Peralatan dan Mesin adalah pengeluaran/biaya yang digunakan untuk pengadaan / penambahan / penggantian, dan peningkatan kapasitas peralatan dan mesin, serta inventaris kantor yang memberikan manfaat lebih dari 12 (dua belas) bulan, dan sampai peralatan dan mesin dimaksud dalam kondisi siap pakai.

3. Belanja Modal Gedung dan Bangunan adalah pengeluaran/biaya yang digunakan untuk pengadaan / penambahan / penggantian dan termasuk pengeluaran untuk perencanaan pengawasan dan pengelolaan pembangunan gedung dan bangunan yang menambah kapasitas sampai gedung dan bangunan dimaksud dalam kondisi siap pakai.

4. Belanja Modal Jalan, irigasi dan jaringan adalah pengeluaran / biaya yang digunakan untuk pengadaan / penambahan / penggantian / peningkatan pembangunan / pembuatan serta perawatan, dan termasuk pengeluaran untuk perencanaan, pengawasan dan pengelolaan jalan irigasi dan jaringan yang menambah kapasitas sampai jalan irigasi dan jaringan dimaksud dalam kondisi siap pakai.

5. Belanja modal fisik lainnya adalah pengeluaran / biaya yang digunkan untuk pengadaan / penambahan / penggantian / peningkatan pembangunan / pembuatan serta perawatan terhadap fisik lainnya yang tidak dapat dikategorikan ke dalam kriteria belanja modal tanah, peralatan dan mesin, gedung dan bangunan, dan jalan irigasi dan jaringan. Termasuk dalam belanja ini adalah belanja modal kontrak sewa beli, pembelian barang-barang kesenian, barang purbakala dan barang untuk museum, hewan ternak dan tanaman, buku-buku dan jurnal ilmiah.

6. Belanja modal dimaksudkan untuk mendapatkan aset tetap pemerintah daerah yaitu peralatan, bangunan, insfrastruktur dan harta tetap lainnya.

\section{Hubungan Logis Antar Variabel}

\section{Pengaruh Pendapatan Asli Daerah terhadap Belanja Modal}

Otonomi daerah mengharapkan pemerintah daerah memiliki kemandirian yang sangat besar dalam keuangan daerah. Peningkatan pajak daerah dan retribusi daerah dapat meningkatkan pendapatan asli daerah (PAD) dan dapat mendorong kinerja ekonomi daerah. Dengan potensi masing-masing daerah dalam mengelola penerimaan daerah diharapkan dapat membiayai segala urusan pemerintahannya, dan tidak mengandalkan transferan dana dari pemerintahan pusat.

Penelitian yang dilakukan oleh Wandira (2013) mengungkapkan bahwa pendapatan asli daerah berpengaruh terhadap pengalokasian anggaran belanja modal. Peningkatan investasi modal (belanja modal) diharapkan mampu meningkatkan tingkat partisipasi (kontribusi publik) terhadap pembangunan yang tercermin dari adanya 
peningkatan pendapatan asli daerah. Berdasarkan paparan tersebut, dirumuskan hipotesis sebagai berikut :

\section{H1 : Pendapatan Asli Daerah berpengaruh terhadap Belanja Modal}

\section{Pengaruh Dana Alokasi Umum terhadap Belanja Modal}

Dana alokasi umum merupakan sejumlah dana dari APBN yang diberikan untuk daerah setiap tahunnya yang digunakan sebagai dana pembangunan. Keterkaitan sangat erat antara transfer dari pemerintah pusat dengan belanja modal. Kenaikan pendapatan asli daerah akan berpengaruh pada jumlah dana alokasi umum yang ditransfer oleh pemerintah pusat. karena dengan banyaknya potensi dari daerah itu sendiri, dana alokasi umum yang ditransfer dari pemerintah semakin sedikit membuat daerah tersebut mandiri dan siap menghadapi otonomi daerah.

Penelitian yang dilakukan oleh Nuarisa (2013) mengungkapkan bahwa dana alokasi umum berpengaruh terhadap belanja modal. Hal ini memberikan adanya indikasi kuat bahwa perilaku belanja daerah khususnya belanja modal akan sangat dipengaruhi sumber penerimaan ini. berdasarkan uraian diatas maka dapat dirumuskan hipotesis sebagai berikut :

\section{H2 : Dana Alokasi Umum berpengaruh terhadap Belanja Modal \\ Pengaruh Dana Alokasi Khusus terhadap Belanja Modal}

Dana alokasi khusus merupakan alokasi dari APBN kepada daerah dengan tujuan mendanai kegiatan khusus yang merupakan urusan pemerintah daerah. Pemanfaatan DAK diarahkan pada kegiatan investasi pembangunan, pengadaan, peningkatan, dan perbaikan sarana dan prasarana fisik dengan umur ekonomis yang panjang, termasuk pengadaan sarana fisik penunjang. Dengan adanya pengalokasian DAK diharapkan dapat mempengaruhi pengalokasian anggaran belanja modal, karena DAK cenderung akan menambah aset tetap yang dimiliki pemerintah guna meningkatkan pelayanan publik.

Dalam penelitian yang dilakukan oleh Nugraeini (2011) menemukan bahwa dana alokasi khusus (DAK) berpengaruh terhadap belanja modal, sama halnya dengan hasil penelitian yang dilakukan oleh Nuarisa (2013). Hal ini mengindikasikan bahwa terdapat hubungan antara pemberian dana transfer dari pemerintah pusat (DAK) dengan alokasi anggaran pengeluaran daerah melalui belanja modal. Berdasarkan penemuan empiris diatas maka menghasilkan hipotesis sebagai berikut :

\section{H3 : Dana Alokasi Khusus berpengaruh terhadap Belanja Modal Kerangka Pemikiran}

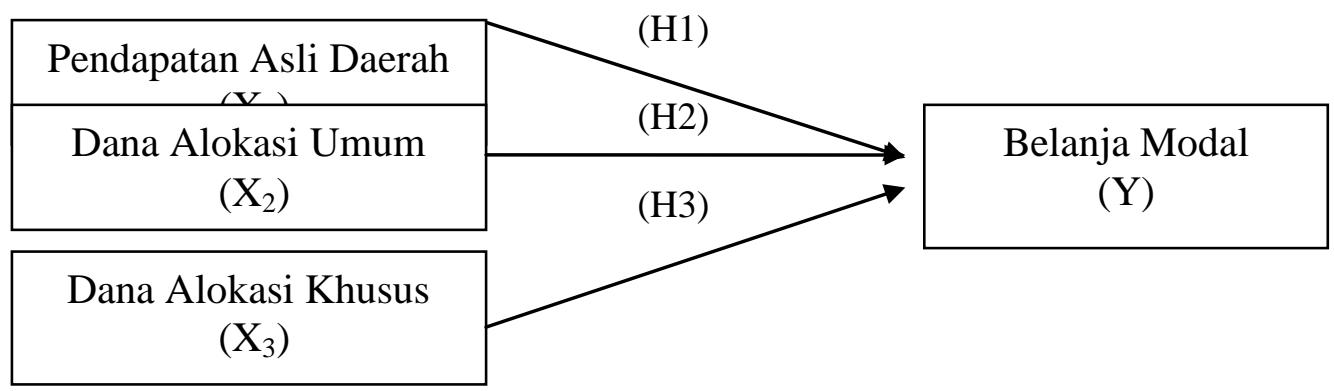




\section{METODE PENELITIAN}

\section{Variabel Penelitian dan Definisi Operasional}

Variabel terkait dalam penelitian ini yaitu Belanja Modal dan Variabel Bebas (Independent Variabels) adalah Pendapatan Asli Daerah, Dana Alokasi Umum dan Dana Alokasi Khusus.

\section{Objek Penelitian dan Unit Sampel}

Objek pada penelitian ini yaitu Propinsi Jawa Tengah dengan Unit Sampel yang

digunakan yaitu Laporan Realisasi APBD tahun 2010-2013.

\section{Populasi dan Penentuan Sampel}

Populasi yang digunakan dalam penelitian ini adalah seluruh Pemerintah Kabupaten/Kota di Propinsi Jawa Tengah yang terdiri dari 29 kabupaten dan 6 kota. Sampel yang digunakan dalam penelitian ini adalah 35 Pemerintah Kabupaten/Kota di Propinsi Jawa Tengah pada tahun 2010-2013. Teknik sampling yang digunakan adalah metode sensus. Metode sensus adalah metode dengan mengambil sampel seluruh kabupaten/kota di Propinsi Jawa Tengah. Penelitian ini mengambil data pada tahun 20102013 dengan jumlah sampel sebanyak 35 daerah. Maka jumlah sampel penelitian keseluruhan menjadi $4 \times 35=140$ data.

\section{Jenis dan Sumber Data}

Data yang digunakan dalam penelitian ini adalah data sekunder, data sekunder merupakan sumber data penelitian yang diperoleh peneliti secara tidak langsung melalui media perantara (diperoleh dan dicatat oleh pihak lain). Sumber data dalam penelitian ini adalah Data Laporan Realisasi APBD tahun 20010-2013 Kabupaten/Kota di Jawa Tengah, yang dapat diperoleh dari situs Dirjen Perimbangan Keuangan Pemerintah Daerah melalui www.djpk.depkeu.go.id dimana data mengenai jumlah realisasi Anggaran Belanja Modal, Pendapatan Asli Daerah (PAD), Dana Alokasi Umum (DAU), dan Dana Alokasi Khusus (DAK).

\section{Metode Pengumpulan Data}

Metode dokumentasi adalah ditujukan untuk memperoleh data langsung dari tempat penelitian, meliputi buku-buku yang relevan, peraturan-peraturan, laporan kegiatan dan data yang relevan dengan penelitian.

\section{Metode Analisis}

Dalam penelitian ini, variabel yang digunakan adalah Pendapatan Asli Daerah, Dana Alokasi Umum, Dana Alokasi Khusus, dan Anggaran Belanja Modal. Untuk dapat melakukan analisis regresi berganda perlu pengujian asumsi klasik sebagai persyaratan dalam analisis agar datanya dapat bermakna dan bermanfaat. Adapun uji asumsi klasik yang digunakan adalah Uji Normalitas, Uji Multikolinieritas, Uji Heteroskedastisitas, Uji Autokorelasi. Analisis Regresi Linier Berganda digunakan untuk mengetahui hubungan secara linear antara variabel independen dengan variabel dependen. Untuk pengujian hipotesis dalam penelitian ini menggunakan pengujian secara parsial (Uji $t$ ), pengujian secara simultan (Uji F) dan Uji Koefisien Determinasi $\left(\mathrm{R}_{2}\right)$ untuk mengetahui prosentase sumbangan pengaruh variabel independen secara serentak terhadap variabel dependen (Y). 


\section{HASIL DAN PEMBAHASAN \\ Deskripsi Obyek Penelitian}

Propinsi Jawa Tengah merupakan salah satu propinsi di Indonesia yang letaknya dibagian tengah pulau jawa. Propinsi Jawa Tengah berbatasan dengan propinsi Jawa Barat di sebelah Jawa Barat, Samudera Hindia dan Daerah Istimewa Yogyakarta di sebelah Selatan, Jawa Timur di sebelah Timur, dan laut Jawa di sebelah utara. Luas wilayahnya $32.548 \mathrm{~km}^{2}$ atau sekitar 25,04\% dari luas Pulau Jawa.

Populasi dalam Penelitian ini yaitu pemerintah kabupaten/kota di Jawa Tengah. Propinsi Jawa Tengah terdiri dari 29 Kabupaten dan 6 Kota. Dalam penelitian ini jumlah (n) sebanyak 140 data, data diperoleh dari Laporan Realisasi APBD tahun 2010-2013 yang terdapat dalam Dirjen Perimbangan Keuangan Pemerintah Daerah tahun 2010-2013. Pemilihan Sampel pada penelitian ini didasarkan pada metode sensus.

\section{Analisis Data}

\section{Statistik Deskriptif}

Descriptive Statistics

\begin{tabular}{|l|r|r|r|r|r|}
\hline & N & \multicolumn{1}{|c|}{ Minimum } & Maximum & \multicolumn{1}{c|}{ Mean } & Std. Deviation \\
\hline Pendapatan Asli Daerah & 140 & 10.305 & 925.919 & $125.433,81$ & $108.062,051$ \\
Dana Alokasi Umum & 140 & 238.069 & 1.197 .315 & $653.957,84$ & $202.458,529$ \\
Dana Alokasi Khusus & 140 & 14.993 & 118.962 & $60.743,82$ & $21.322,815$ \\
Belanja Modal & 140 & 25.479 & 591.011 & $156.361,08$ & $85.837,027$ \\
Valid N (listwise) & 140 & & & & \\
\hline
\end{tabular}

Tabel diatas menggambarkan deskripsi variabel-variabel secara statistik dalam penelitian ini. Minimum adalah nilai terkecil dari nilai suatu rangkaian pengamatan, maksimum adalah nilai terbesar dari suatu rangkaian pengamatan, mean (rata-rata) adalah hasil penjumlahan nilai seluruh data dibagi dengan banyaknya data, sementara standar deviasi adalah akar dari jumlah kuadrat dari selisih nilai data dengan rata-rata dibagi dengan banyaknya data.

\section{Uji Asumsi Klasik}

Setelah dilakukan Uji Normalitas dapat disimpulkan data penelitian berdistribusi normal sedangkan setelah dilakukan uji pelanggaran asumsi klasim yang terdiri dari Uji Multikolinearitas, Uji Heterokedastisitas dan Uji Autokorelasi dapat disimpulkan tidak terjadi pelanggaran asumsi klasik.

\section{Uji Regresi Linear Berganda}

Hasil analisis regresi adalah berupa koefisien untuk masing-masing variabel independen. Koefisien diperoleh dengan cara memprediksi nilai variabel dependen dengan suatu persamaan. Berikut ini adalah hasil perhitungan regresi : 


\section{Hasil Uji Regresi Linear Berganda}

Coefficients $^{\mathrm{a}}$

\begin{tabular}{|c|c|c|c|c|c|c|}
\hline & \multirow[b]{2}{*}{ Model } & \multicolumn{2}{|c|}{$\begin{array}{l}\text { Unstandardized } \\
\text { Coefficients }\end{array}$} & \multirow{2}{*}{\begin{tabular}{|c}
$\begin{array}{c}\text { Standardized } \\
\text { Coefficients }\end{array}$ \\
Beta \\
\end{tabular}} & \multirow[b]{2}{*}{$\mathrm{t}$} & \multirow[b]{2}{*}{ Sig. } \\
\hline & & B & Std. Error & & & \\
\hline \multirow[t]{4}{*}{1} & (Constant) & -12055.595 & 16036.785 & & -.752 & .454 \\
\hline & $\begin{array}{l}\text { Pendapatan Asli } \\
\text { Daerah }\end{array}$ & .352 & .114 & 247 & 3.088 & .002 \\
\hline & Dana Alokasi Umum & .187 & .037 & .554 & 5.021 & .000 \\
\hline & Dana Alokasi Khusus & -.036 & .320 & -.011 & -.113 & .910 \\
\hline
\end{tabular}

a. Dependent Variable: Belanja Modal

Atas dasar hasil analisis menggunakan metode analisis regresi linear berganda dengan menggunakan tingkat signifikansi sebesar 5\% diperoleh persamaan berikut : $\mathrm{Y}=-12055,595+0,352 \mathrm{PAD}+0,187 \mathrm{DAU}-, 036 \mathrm{DAK}+e$

Koefisien PAD dan DAU bernilai positif hal ini berarti bahwa Belanja Modal akan mengalami peningkatan, sedangkan Koefisien DAK bernilai negatif hal ini berarti bahwa Belanja Modal akan mengalami penurunan.

Uji Koefisien Determinasi $\left(\mathbf{R}^{2}\right)$

Koefisien determinasi menunjukkan seberapa besar variabel bebas dapat menjelaskan variabel dependen yang dinyatakan dalam persen (\%). Hasil pengujian dapat dilihat pada tabel berikut ini :

\section{Hasil Uji Koefisien Determinasi}

Model Summary

\begin{tabular}{|l|l|l|l|l|}
\hline Model & $R$ & R Square & Adjusted R Square & $\begin{array}{l}\text { Std. Error of the } \\
\text { Estimate }\end{array}$ \\
\hline 1 & $.701^{\mathrm{a}}$ & .492 & .480 & $47.369,950$ \\
\hline
\end{tabular}

a. Predictors: (Constant), Dana Alokasi Khusus, Pendapatan Asli Daerah, Dana Alokasi Umum

Berdasarkan hasil pengujian nilai koefisien determinasi yang ditunjukkan dengan adjusted $R$ square adalah sebesar 0,480. Hal ini dapat diartkan bahwa variabel Pendapatan asli daerah, dana alokasi umum, dan dana alokasi khusus dapat menjelaskan variabel belanja modal sebesar $48 \%$ sedangkan sisanya 52\% dijelaskan oleh variabel lain yang tidak diamati dalam penelitian ini.

\section{Uji Simultan (Uji F)}

Pengujian ini dilakukan untuk mengetahui apakah Pendapatan Asli Daerah, Dana Alokasi Umum, dan Dana Alokasi khusus secara bersama-sama berpengaruh terhadap Belanja Modal. Hasil pengujian dapat dilihat dari tabel berikut ini :

\section{Hasil Uji Simultan (Uji F)}

\begin{tabular}{|ll|ll|l|l|l|l|}
\hline \multicolumn{2}{|c|}{ ANOVA $^{\mathbf{b}}$} \\
\hline \multirow{2}{*}{$\begin{array}{ll}\text { Model } \\
1\end{array}$} & $\begin{array}{l}\text { Sum } \\
\text { Squares }\end{array}$ & of & Df & Mean Square & F & Sig. \\
\hline & Residual & $2.758 \mathrm{E} 11$ & 3 & $9.192 \mathrm{E} 10$ & 40.964 & $.000^{\mathrm{a}}$ \\
& $2.850 \mathrm{E} 11$ & 127 & $2.244 \mathrm{E} 9$ & & \\
\hline
\end{tabular}




\begin{tabular}{|l|l|l|l|l|l|}
\hline Total & $5.607 \mathrm{E} 11$ & 130 & & & \\
\hline
\end{tabular}

a. Predictors: (Constant), Dana Alokasi Khusus, Pendapatan Asli Daerah, Dana Alokasi Umum

b. Dependent Variable: Belanja Modal

Hasil pengujian model regresi diperoleh nilai $F$ tabel sebesar 40,964 dan nilai signifikansi sebesar $0,000<\mathrm{a}=0,05$ maka dapat disimpulkan bahwa secara bersamasama variabel pendapatan asli daerah, dana alokasi umum, dan dana alokasi khusus secara simultan berpengaruh terhadap belanja modal. Dengan demikian model regresi layak digunakan.

Uji $\mathrm{t}$ pada dasarnya digunakan untuk menguji pengaruh satu variabel independen secara parsial dalam menerangkan variasi variabel dependen. Berikut ini adalah hasil uji t yang disajikan :

\section{Hasil Uji t \\ Coefficients $^{\mathrm{a}}$}

\begin{tabular}{|c|c|c|c|c|c|c|}
\hline & \multirow[b]{2}{*}{ Model } & \multicolumn{2}{|c|}{$\begin{array}{l}\text { Unstandardized } \\
\text { Coefficients }\end{array}$} & \multirow{2}{*}{\begin{tabular}{|c}
$\begin{array}{c}\text { Standardized } \\
\text { Coefficients }\end{array}$ \\
Beta \\
\end{tabular}} & \multirow[b]{2}{*}{$\mathrm{t}$} & \multirow[b]{2}{*}{ Sig. } \\
\hline & & B & Std. Error & & & \\
\hline \multirow[t]{4}{*}{1} & (Constant) & $\begin{array}{l}- \\
5\end{array}$ & 16036.78 & & -.752 & .454 \\
\hline & $\begin{array}{l}\text { Pendapatan Asli } \\
\text { Daerah }\end{array}$ & .352 & .114 & .247 & 3.088 & .002 \\
\hline & Dana Alokasi Umum & .187 & .037 & .554 & 5.021 & .000 \\
\hline & Dana Alokasi Khusus & -.036 & .320 & -.011 & -.113 & .910 \\
\hline
\end{tabular}

a. Dependent Variable: Belanja Modal

\section{Pengujian Hipotesis (H1)}

Berdasarkan pada tabel diatas, maka dapat diketahui bahwa secara parsial pendapatan asli daerah berpengaruh terhadap belanja modal. Hal ini dibuktikan dengan signifikansi 0,002 $<0,05$ dan nilai $\mathrm{t}_{\text {hitung }} 3,088>$ dengan $\mathrm{t}_{\text {tabel }} 1,9782$. Dengan demikian $\mathrm{t}_{\text {hitung }}$ berada pada daerah $\mathrm{H}_{0}$ ditolak dan $\mathrm{H}_{1}$ diterima maka angka tersebut menunjukkan nilai yang signifikan yang artinya terdapat pengaruh pendapatan asli daerah terhadap belanja modal.

\section{Pengujian Hipotesis (H2)}

Berdasarkan pada tabel diatas, maka dapat diketahui bahwa secara parsial dana alokasi umum berpengaruh terhadap belanja modal. Hal ini dibuktikan dengan signifikansi $0,000<0,05$ dan nilai $t_{\text {hitung }} 5,021>$ dengan $t_{\text {tabel }} 1,9782$. Dengan demikian $\mathrm{t}_{\text {hitung }}$ berada pada daerah $\mathrm{H}_{0}$ ditolak dan $\mathrm{H}_{1}$ diterima maka angka tersebut menunjukkan nilai yang signifikan yang artinya terdapat pengaruh dana alokasi umum terhadap belanja modal.

\section{Pengujian Hipotesis (H3)}

Berdasarkan pada tabel diatas, maka dapat diketahui bahwa secara parsial dana alokasi khusus tidak berpengaruh terhadap belanja modal. Hal ini dibuktikan dengan signifikansi $0,910>0,05$ dan nilai $t_{\text {hitung }}-, 113<$ dengan $t_{\text {tabel }} 1,9782$. Dengan demikian $\mathrm{t}_{\text {hitung }}$ berada pada daerah $\mathrm{H}_{0}$ diterima dan $\mathrm{H}_{1}$ ditolak maka angka tersebut menunjukkan 
nilai yang tidak signifikan yang artinya tidak terdapat pengaruh dana alokasi khusus terhadap belanja modal.

\section{Pembahasan}

\section{Pengaruh Pendapatan Asli Daerah terhadap Belanja Modal}

Pengujian hipotesis 1 dalam penelitian ini adalah untuk menguji apakah pendapatan asli daerah berpengaruh terhadap belanja modal. Hasil penelitian menunjukkan nilai $\mathrm{t}$ sebesar 3,088 dan nilai koefisien sebesar 0,352 dengan tingkat signifikansi sebesar 0,002 berada lebih rendah pada $a=0,05$. Hal ini dapat diartikan bahwa semakin tinggi PAD maka pengeluaran pemerintah atas belanja modal pun akan semakin tinggi. Sejalan dengan PP No. 58 tahun 2005 tentang pengelolaan keuangan daerah yang menyatakan bahwa PAD disusun sesuai dengan kebutuhan penyelenggaraan pemerintahan dan kemampuan pendapatan daerah. Artinya, disetiap penyusunan APBD, jika pemerintah daerah akan mengalokasikan belanja modal maka harus benar-benar disesuaikan dengan kebutuhan daerah dengan mempertimbangkan pendapatan asli daerah yang diterima. Hasil penelitian yang dilakukan oleh Nuarisa (2013) semakin tinggi pendapatan asli daerah maka pengeluaran pemerintah atas belanja modalpun akan semakin tinggi dan apabila pemerintah daerah memiliki pendapatan asli daerah yang rendah maka pengeluaran pemerintah atas belanja modal juga rendah. Dapat disimpulkan bahwa pendapatan asli daerah mempengaruhi belanja modal. Penelitian ini menunjukkan bahwa pendapatan asli daerah dapat meningkatkan belanja modal.

Hasil penelitian ini konsisten dengan penelitian Wandira (2013) dan Nuarisa (2013) yang menunjukkan bahwa pendapatan asli daerah berpengaruh terhadap belanja modal.

\section{Pengaruh Dana Alokasi Umum terhadap Belanja Modal}

Pengujian hipotesis 2 dalam penelitian ini adalah untuk menguji apakah dana alokasi umum berpengaruh terhadap belanja modal. Hasil penelitian menunjukkan $\mathrm{t}$ sebesar 5,021 dan nilai koefisien sebesar 0,187 dengan tingkat signifikansi sebesar 0,000 berada lebih rendah pada $a=0,05$. Dapat disimpulkan bahwa dana alokasi umum mempengaruhi belanja modal. Hasil ini mengindikasikan bahwa terdapat hubungan antara pemberian dana transfer dari pemerintah yaitu dana alokasi umum, dengan alokasi pengeluaran daerah melalui alokasi belanja modal juga meningkat. Semakin tinggi dana alokasi umum maka alokasi belanja modal juga meningkat. Hal ini disebabkan karena daerah yang memiliki pendapatan dana alokasi umum yang besar maka alokasi untuk anggaran belanja modal akan meningkat.

Hasil penelitian ini konsisten dengan penelitian Wandira (2013) dan Nuarisa (2013) yang menunjukkan bahwa dana alokasi umum berpengaruh terhadap belanja modal.

\section{Pengaruh Dana Alokasi Khusus terhadap Belanja Modal}

Pengujian hipotesis 3 dalam penelitian ini adalah untuk menguji apakah dana alokasi khusus berpengaruh terhadap belanja modal. Hasil penelitian menunjukkan $\mathrm{t}$ sebesar -,113 dan nilai koefisien sebesar -,036 dengan tingkat signifikansi sebesar 0,910 berada lebih tinggi pada $a=0,05$. Dapat disimpulkan bahwa dana alokasi khusus tidak mempengaruhi belanja modal. Hal ini disebabkan karena nilai dana alokasi khusus yang diterima pemerintah daerah digunakan untuk mendanai kegiatan khusus yang merupakan urusan daerah. Kegiatan khusus yang dimaksud adalah sesuai dengan fungsi yang ditetapkan oleh APBN, misalnya untuk layanan kepentingan publik, pendidikan dan lainlain. 
Dana Alokasi Khusus tidak berpengaruh terhadap Belanja Modal dikarenakan pada tahun terakhir yaitu 2013 Dana Alokasi Khusus cenderung mengalami penurunan, dapat dilihat pada tabulasi data. Hasil penelitian ini konsisten dengan peneliti sebelumnya oleh Darmayasa \& Suandi (2014) yang menyatakan DAK tidak berpengaruh terhadap alokasi belanja modal. DAK bukan merupakan faktor penentu pengalokasian belanja modal pada pemerintah provinsi untuk tahun amatan 2011-2013. Ferdian (2013) DAK termasuk di dalamnya $40 \%$ dari dana reboisasi. kewenangan dalam pengalokasian DAK relatif terbatas karena dana tersebut pada dasarnya dikaitkan dengan pembiayaan kegiatan tertentu termasuk kegiatan reboisasi.

Alasan utama yang menyebabkan DAK tidak berpengaruh terhadap belanja modal adalah kecilnya DAK yang diterima oleh pemerintah provinsi di Indonesia, yaitu hanya sebesar $1 \%$ terhadap total APBD. Jumlah belanja modal yang bersumber dari DAK hanya sebesar 7\% sehingga dapat disimpulkan walaupun DAK merupakan special grant, untuk pembangunan infrastruktur namun karena prosentasenya kecil bukan merupakan faktor penentu alokasi belanja modal untuk tahun pengamatan 2011-2013 (Darmayasa \& Suandi, 2014).

\section{PENUTUP}

\section{Simpulan}

Penelitian ini menguji pengaruh pendapatan asli daerah (PAD), dana alokasi umum (DAU), dana alokasi khusus (DAK) dan Belanja Modal pada kabupaten/kota di Propinsi Jawa Tengah dari tahun 2010-2013.

Berikut adalah kesimpulan yang dapat diambil dari peneliti ini :

1. Terdapat pengaruh Pendapatan Asli Daerah (PAD) terhadap Pengalokasian Anggaran Belanja Modal.

2. Terdapat pengaruh Dana Alokasi Umum (DAU) berpengaruh terhadap Pengalokasian Anggaran Belanja Modal.

3. Tidak Terdapat pengaruh Dana Alokasi Khusus (DAK) terhadap Pengalokasian Anggaran Belanja Modal.

\section{Saran}

1. Pemerintah daerah diharapkan untuk lebih mengembangkan sektor-sektor ekonomi daerah agar dapat meningkatkan pendapatan asli daerah agar lebih mandiri dalam mendanai seluruh aktivitas pemerintahan dalam rangka pelaksanaan otonomi daerah.

2. Pemerintah harus dapat mengoptimalkan penerimaan pendapatan asli daerah agar tidak terjadi ketimpangan fiskal.

3. Peningkatan pemerintah daerah dalam belanja modal diharapkan mampu meningkatkan kualitas layanan publik dan pada akhirnya dapat meningkatkan kontribusi publik terhadap pembangunan yang timbul dari adanya peningkatan pendapatan asli daerah.

\section{Keterbatasan Penelitian}

Peneliti ini diperoleh hasil Adjusted $\mathrm{R}$ square sebesar 0,48 dengan tiga variabel independen. Dengan nilai Adjusted $\mathrm{R}$ square sebesar 0,48 kurang baik model regresi dengan data yang ada. Sehingga untuk peneliti selanjutnya agar bisa meningkatkan nilai Adjusted R squarenya lebih mendekati angka 1, dengan menambahkan variabel lain seperti Dana Bagi Hasil, Sisa Lebih Pembiayaan Anggaran dan Luas Wilayah. 


\section{Agenda Penelitian Yang Akan Datang}

1. Pada penelitian yang akan datang diharapkan untuk memperbanyak sensus yang digunakan agar hasilnya lebih representative terhadap populasi yang dipilih.

2. Variabel yang digunakan dalam penelitian yang akan datang diharapkan lebih bervariasi dengan menambahkan variabel independen lain seperti kebijakan pemerintah dan indeks pembangunan manusia.

3. Dapat menambahkan objek penelitian seperti wilayah Jawa Barat ataupun Jawa Timur.

\section{DAFTAR PUSTAKA}

Adi, P. H. 2006. Hubungan antara pertumbuhan ekonomi daerah, Belanja Pembangunan dan Pendapatan Asli Daerah (Studi Pada Kabupaten dan Kota se-Jawa-Bali). Simposium Nasional Akuntansi IX. Padang .

BPS. 2009-2013. Jawa Tengah Dalam Angka.

Darmayasa, I. N., \& Suandi, I. K. 2014. Faktor Penentu Alokasi Belanja Modal dalam APBD pada Pemerintah Provinsi. SNA 17 Mataram, Lombok, 24-27.

Ferdian, Y. 2013. Pengaruh Pendapatan Asli Daerah, Dana Perimbangan, dan Lain-lain Pendapatan Yang Sah Terhadap Belanja Daerah. Artikel Universitas Negeri Padang .

Kawedar, W. d. 2008. Akuntansi Sektor Publik. Semarang: Undip.

Mentayani, I., \& Rusmanto. 2013. Pendapatan Asli Daerah, Dana Alokasi Umum dan Sisa Lebih Pembiayaan Anggaran Terhadap Belanja Modal Pada Kota dan Kabupaten di Pulau Kalimantan. Jurnal InFestasi. 9(2).

Nuarisa, S. A. 2013. Pengaruh Pendapatan Asli Daerah, Dana Alokasi Umum dan Dana Alokasi Khusus terhadap Pengalokasian Anggaran Belanja Modal. Accounting Analysis Journal . 2(1) ISSN 2252-6765.

Undang-Undang Nomor 32 tahun 2004 tentang Pemerintah Daerah.

Undang-Undang Nomor 33 tahun 2004 tentang Perimbangan Keuangan antara Pemerintah Pusat dan Pemerintah Daerah.

Wandira, A. G. 2013. Pengaruh Pendapatan asli daerah, dana alokasi umum, dana alokasi khusus dan dana bagi hasil terhadap pengalokasian Belanja Modal. Accounting Analysis Journal. 2(1) ISSN 2252-6765.

Wenas, C. L., Kumenaung, A., \& Rompas, W. 2014. Pengaruh Dana Alokasi Umum (DAU), dan Pendapatan Asli Daerah (PAD) terhadap Belanja Daerah pemerintah Kota Manado. Jurnal Berkala Ilmiah Efisiensi , 14 (1). 